\title{
Haza, avagy a visszatérés mítosza
}

Néhány éve történt, hogy egy kutatást vezettem, amiben azt vizsgáltuk, hogy miként viszonyulnak a bevándorlók a befogadó ország állampolgárságának megszerzéséhez. Honosítási statisztikákat elemeztünk, kerestük a mintázatokat és összefüggéseket annak fényében, hogy honnan és mikor érkezett valaki, és hogy milyenek a jövőre vonatkozó tervei. A munka eredményeiből egy egész tanulmánykötet született a Kisebbségkutató Intézet kiadásában - kutatói életutam egyik fontos állomása.

A kutatás során több személyes interjút készítettünk Magyarországon élő bevándorlókkal. Egy alkalommal egy idősebb afgán férfival beszélgettem az egyik budapesti mecset előterében, a szőnyegen ülve. Mérnökember, a nyolcvanas évek közepe óta élt Magyarországon, megbecsült szakember, egyetemi oktató, az egyik muszlim közösség meghatározó tagja volt. Amikor arról kérdeztem, hogy ennyi év után, ilyen stabil egzisztenciával, a nyelvet ilyen jól beszélve miért nem folyamodott még magyar állampolgárságért, így válaszolt:

„Tudod, amikor kisgyerek voltam, a nyarakat mindig nagyapám vidéki birtokán töltöttük. A ház mögött gyümölcsös volt, magas, zöld fü a fák alatt, egy domboldal, amin le tudtunk szaladni a völgyben csörgedező patakig. Itt játszadoztunk, és máig emlékszem a szagokra, a fényre, a gyümölcs ízére, és nagyapám házára. Ahogy öregszem, egyre többet gondolok erre, és úgy érzem, hogy ha állampolgárságot kérnék, akkor elárulnám ezt az emléket."

Egy év sem telt el a beszélgetésünk óta, és visszaköltözött Afganisztánba...

Az egyik első ,komoly” migrációs szakirodalom, ami a kezembe került, Muhammad Anwar The Myth of Return (A visszatérés mitosza) címü könyve volt. Az 1970-es évek végén íródott könyv egy nagyon alapos szociológiai elemzés egy brit város pakisztáni közösségéröl. A szerző arra a következtetésre jut, hogy a szülőhazába való visszatérés lehetősége, az erről való gondolkodás, ennek folyamatos megbeszélése egy nagyon erős kötőelem egy bevándorolt közösség életében. Fontos akkor is, ha a hazatérés soha nem valósul meg - ennek kimondása gyakran tabu, erős normatív korlátokba ütközik. A hétköznapi viselkedés, az egyéni, családi döntések is gyakran alárendelődnek a „mítosznak” való megfelelésnek: nem

A szerző szociológus, a Társadalomtudományi Kutatóközpont Kisebbségkutató Intézet munkatársa. E-mail: Kovats.Andras@tk.hu 
szerzünk ingatlant, nem válunk állampolgárrá, nem változtatunk nevet, mert „hátha, egyszer, mégis...”

Kisgyerekkori emlékeim közé tartoznak egy kis csallóközi faluban tett látogatások, amikre nagyszüleimet kísértük el. A temető meglátogatása, a ház szemrevételezése az elhaladó autóból, a szomszédos faluban tartott búcsú meglátogatása, nehezen gördülö beszélgetések az ottmaradt rokonokkal.

Mosonmagyaróváron születtem, ahova a Csallóközből 1947-ben Baranyába kitelepített nagyszüleim azért költöztek 1953-ban, mert elterjedt a hír: a Sztálin halálát követő enyhülés eredményeképp lehet, hogy haza lehet térni. Nem így lett, aztán meg már késő volt - eltelt egy küszködésekkel, örömmel és bánattal teli élet, és teltek a sírok az óvári temetőben...

Huszonöt éve dolgozom bevándorlókkal és menekültekkel, az otthon, a haza, az eljövetel és a visszatérés állandó kérdések ebben a munkában. Egyre több élmény, emlék, történet gyülik össze bennem, ami erről szól. Az, hogy miért kell a földig rombolt szlavóniai falut ugyanott és ugyanúgy felépíteni, ahol, és ahogy ezer éve állt, hogy miért kell a Ghánából Libériába két évtized után hazatérő családoknak a tüzhelyeket is magukkal vinni a repülön, vagy hogy miért kell egy Londonban átdolgozott hét után az egész szombat estét egy külvárosi közösségi házban tölteni magyar néptáncot járva, langyos Borsodi vagy Kőbányai sört kortyolgatva müanyag pohárból.

Az otthon, a haza akkor jelent igazán sokat, ha hiányzik. És ha ez a hiány már nem személyes emlék, hanem csak a közösség által ébren tartott mítoszok és rítusok összessége, akkor a hozzá füződő viszony is átalakul. Anwar kutatási eredményeinek továbbgondolása nagyjából egy emberöltővel később történt meg; a bevándorolt közösségek második és harmadik generációja esetén már nem visszatérésről beszélünk, hanem az „anyaországhoz való kötődésről” (homeland attachment). Nyári nyelvtanfolyamok, rokonlátogatások, az anyaországhoz mint kulturális és spirituális forráshoz való viszony határozzák meg ezt a fázist. Az anyanyelv már csak a gyerekkor és a szülői ház nyelve, a hazatérés a szülők és nagyszülők álma, a haza, az otthon már itt van, de azért még van egy ország, van egy nép, egy közösség, amihez szintén tartozunk, és ami minket is odatartozónak tekint. Számtalan újabb kérdés, számtalan értelmezési lehetőség arra, hogy miként történik mindez, ki hogyan éli ezt meg, jó-e vagy rossz mindez, és mihez kezdjen vele az, aki eljött valahonnan, és azok, akik ott maradtak. 